\title{
Acidic calcium stores open for business: expanding the potential for intracellular $\mathrm{Ca}^{2+}$ signaling
}

\author{
Sandip Patel ${ }^{\#}$ and Roberto Docampo* \\ \# Department of Cell and Developmental Biology, University College London, London WC1E 6BT, \\ England, UK \\ * Center for Tropical and Emerging Global Diseases and Department of Cellular Biology, University \\ of Georgia, Athens, 30602, USA
}

\begin{abstract}
Changes in cytosolic calcium concentration are crucial for a variety of cellular processes in all cells. It has long been appreciated that calcium is stored and released from intracellular calcium stores such as the endoplasmic reticulum. However, emerging evidence indicates that calcium is also dynamically regulated by a seemingly disparate collection of acidic organelles. Here, we review the defining features of these acidic calcium stores and highlight recent progress in understanding the mechanisms of uptake and release of calcium from these stores. We also examine the nature of calcium buffering within the stores and summarize the physiological and patho-physiological significance of these ubiquitous organelles in calcium signaling.
\end{abstract}

\section{Introduction}

Changes in cytosolic calcium concentration constitute an evolutionarily conserved signaling pathway crucial for a huge number of physiological events [1]. Whilst in the resting cells, calcium concentration in the cytosol is maintained at low levels, typically $100 \mathrm{nM}$, the concentration can increase dramatically in response to a variety of environmental cues such as stressors and hormones [1]. These calcium signals display spectacular spatiotemporal complexity. Not surprisingly, deviant calcium signals are associated with cellular dysfunction and death [2]. Thus, understanding the mechanism by which calcium signals are generated is of up most importance in understanding how cells ultimately function correctly.

Dynamic changes in calcium have been extensively studied in animal cells. Calcium is derived from the extracellular space and/or intracellular calcium stores [3]. The endoplasmic reticulum is by far the best studied releasable calcium store possessing a well defined repertoire of calcium channels, pumps and buffers [4]. Calcium, however, is also stored in a variety of acidic organelles in both prokaryotic and eukaryotic cells. This was recognized as early as the 1970s using histochemical and electron microscopy techniques [5]. In this review, we describe the

\footnotetext{
\#Corresponding author: Department of Cell and Developmental Biology, University College London, London WC1E 6BT, England, UK; Phone: 44207679 6540; Fax: 44207916 7968; patel.s@ucl.ac.uk.

${ }^{*}$ Corresponding author: Center for Tropical and Emerging Global Diseases and Department of Cellular Biology, University of Georgia, 350B Paul D. Coverdell Center, 500 D.W. Brooks Dr., Athens, GA 30602, Phone: 706-542-8104; Fax: 706-542-9493; rdocampo@uga.edu

Publisher's Disclaimer: This is a PDF file of an unedited manuscript that has been accepted for publication. As a service to our customers we are providing this early version of the manuscript. The manuscript will undergo copyediting, typesetting, and review of the resulting proof before it is published in its final citable form. Please note that during the production process errors may be discovered which could affect the content, and all legal disclaimers that apply to the journal pertain.
} 
form of these acidic calcium stores, the mechanisms of calcium handling by these stores and the functional roles of these ubiquitous organelles in calcium signalling.

\section{Acidic calcium stores: Form and function}

Here, we classify a number of organelles, which at first sight appear very different, as acidic calcium stores (Fig. 1). This classification is based on their acidic interior and the presence of calcium. Acidic calcium stores include acidocalcisomes, vacuoles, endosomes, lysosomes, lysosome-related organelles, secretory granules and the Golgi complex (Fig. 1). Calcium uptake into acidic calcium stores is mediated by either calcium pumps or exchangers (Box 1, Table 1). Acidic calcium stores also possess several calcium-permeable channels such as members of the transient receptor potential superfamily, the two-pore channels and $\mathrm{IP}_{3} /$ ryanodine receptors in order to effect calcium release (Box 2, Table 2).

\section{Box 1}

\section{Mechanism of calcium uptake into acidic calcium stores}

Calcium ATPases are pumps found in membranes of various organelles and the plasma membrane that transport calcium against its concentration gradient from the cytosol into the lumen or the extracellular space [78,79] (Figure I). This process requires hydrolysis of ATP. In trypanosomes and Toxoplasma, a calcium ATPase related to the plasma membrane type calcium ATPase (PMCA) in mammals [78] is located in acidocalcisomes where it is responsible for filling of these stores with calcium [6,7]. ATPases of the same subtype have been described in the vacuoles of Dictyostelium [11], yeast [12] and plants [80]. Whether they are also present in the acidic calcium stores of animal cells is not known.

Sarco/endoplasmic reticulum ATPases (SERCAs), as their name implies, fill endoplasmic reticulum calcium stores with calcium [78]. These pumps however have also been implicated in the filling of acidic calcium stores such as the Golgi [81]. Additionally, in a number of secretory granules, such as large dense core granules of PC12 cells [37], insulin storage granules of mouse pancreatic beta-cells [82] and bovine adrenal chromaffin granules [35], $\mathrm{Ca}^{2+}$ accumulation was shown to be ATP-dependent and sensitive to inhibitors commonly used against SERCA-type pumps (e.g. thapsigargin, cyclopiazonic acid). Results with human platelets also suggest that $\mathrm{Ca}^{2+}$ uptake into acidic stores is driven at least in part by SERCA-type $\mathrm{Ca}^{2+}$-ATPase $[83,84]$.

The third class of calcium pumps are the secretory pathway $\mathrm{Ca}^{2+}$ ATPases (SPCAs) [79]. These proteins mediate $\mathrm{Ca}^{2+}$ uptake in the Golgi [81] and certain secretory vesicles [36]. SPCA was first described in yeast and named Pmrlp [73]. In addition to calcium, it is also able to transport $\mathrm{Mn}^{2+}$ and both ions are needed for many enzymatic reactions in the Golgi apparatus [81].

Finally, isolated lysosomes from neutrophils [85] and fibroblasts [86] have been reported to take up $\mathrm{Ca}^{2+}$ and a $\mathrm{Ca}^{2+}$-ATPase activity has been measured in isolated lysosomes from rat liver $[87,88] . \mathrm{Ca}^{2+}$-ATPase activity has also been detected in synaptic vesicles [89]. In all cases however the molecular nature of the pump has not been identified.

The large concentration gradient of protons across the membranes of acidic calcium stores can be readily utilized to transport calcium into the vesicle lumen against its concentration gradient. This process is mediated by calcium hydrogen exchangers (CAXs) [90]. CAXs have been characterized in acidocalcisomes of protists [6] and in both yeast [91] and plant [92] vacuoles. Interestingly, although the genes encoding CAXs are present in the genomes of some animals (e.g fish and amphibians), they are absent in mammalian genomes [90]. Nevertheless, calcium hydrogen exchange activity has been reported in isolated melanosomes from retinal pigment epithelial cells [93], large dense core granules of PC12 
cells [37] and synaptic vesicles of sheep brain cortex [89]. One possibility to explain this apparent paradox is that, in mammals, calcium hydrogen exchange activity might not be mediated by a single protein but instead through the concerted activity of sodium hydrogen exchangers and sodium calcium exchangers, the net effect being the transport of calcium ions into the lumen and protons out of the lumen. Indeed, sodium calcium exchange activity has been detected in secretory granules $[37,94]$ and at least one member of the sodiumcalcium exchanger family NCKX5 is an intracellular protein present in the melanosomes and/or Golgi [71,95].

\section{Box 2}

\section{Mechanisms of calcium release from acidic calcium stores}

Transient receptor potential (TRP) channels are a large superfamily of distantly related cation channels involved in the transduction of sensory stimuli [41] (Figure II). In yeast, yvc1 (TRPY1), has been identified as a calcium-permeable channel localized to the vacuole that can be activated by cytosolic calcium and membrane stretch $[15,96]$. TRP mucolipins (TRPML) are a subfamily of TRP channels that, together with the TRP polycystins, constitute the group II TRP channels [41]. TRPMLs are so-named based on the discovery that the gene encoding the founding member (TRPML1) in humans is mutated in the lysosomal storage disease mucolipidosis IV [97]. Mammals possess genes encoding three TRPML proteins [97]. TRPML1 localizes to the late endosomes/lysosomes, TRML2 to recycling endosomes, late endosomes/lysosomes and the plasma membrane, and TRPML3 throughout the endolysosomal system and plasma membrane [97]. The channel properties of TRPMLs are subject to debate, although several studies suggest that they can function as calcium channels [97]. These channels show a wide tissue distribution in mammals, suggesting a general role for TRPMLs in regulating calcium fluxes from the endo-lysosomal system. The physiological trigger for calcium release by TRPMLs, however, remains to be established.

Two-pore channels (TPCs) are poorly characterized ion channels that were originally identified based on sequence similarity to voltage-sensitive sodium and calcium channels $[16,98]$. The latter two comprise four repeats, whereas TPCs are unique in that they posses only two of these repeats $[16,98]$. In plants, TPCs localize to the vacuole and are likely the molecular correlate of the slow vacuolar (SV) current [17]. SV channels are calcium permeable and activated by cytosolic calcium and positive membrane potentials [17]. Consistent with this mode of activation, plant TPCs possess a pair of putative EF-hands within the cytosolic loop, which likely bind to calcium, and a series of positively charged amino residues within the predicted fourth transmembrane regions of each repeat that are likely to serve as voltage sensors $[16,17,98]$. Little is known concerning the properties of the animal TPCs.

It is well established that mobilisation of endoplasmic reticulum calcium stores can be mediated via inositol trisphosphate and ryanodine receptors [1]. These calcium channels are gated by the calcium-mobilizing messengers inositol trisphosphate and cyclic ADPribose, respectively, and share many structural and functional similarities [1]. Although their predominant location is within the membranes of the endoplasmic reticulum, these channels can also be located within additional subcellular locales, including acidic calcium stores. Paramecium posses an expanded family of inositol trisphosphate receptors and one of the isoforms localizes to the contractile vacuole [99]. Additionally, both inositol trisphosphate and cyclic ADP-ribose have both been reported to release calcium from the plant vacuole [100], but genes encoding receptors for inositol trisphosphate and ryanodine are apparently absent from plant and yeast genomes. In animal cells, inositol trisphosphate 
receptors have been localized to the acrosome from sperm [101], and inositol trisphosphateinduced calcium release has been demonstrated from secretory vesicles isolated from the adrenal medulla and several other secretory cell types [34]. Cyclic ADP-ribose has been reported to release calcium from zymogen granules or a closely associated acidic organelle from exocrine pancreatic acinar cells [102] and dense core vesicles in a clonal pancreatic beta cell line [36]. Additionally, caffeine (a pharmacological activator of ryanodine receptors) was shown to mediate calcium release from isolated melanosomes [93]. Clear evidence has also been obtained for functional inositol trisphosphate receptors on the Golgi complex [39]. Thus, receptors for inositol trisphosphate and ryanodine likely mediate calcium release from acidic calcium stores as well as from the endoplasmic reticulum.

\section{Acidocalcisomes}

Based on its presence in prokaryotes, the earliest calcium-containing acidic compartment that appeared during evolution was probably the acidocalcisome [6]. The acidocalcisome was first identified in bacteria and called the volutin granule [6]. Recent work in Agrobacterium tumefaciens and Rhodospirillum rubrum has demonstrated that acidocalcisomes are membrane bounded and express a vacuolar proton pyrophosphatase (V-PPase) that drives acidification [6]. Acidocalcisomes in both prokaryotes and eukaryotes such as trypanosomes are characterized by their electron-density in the absence of staining and are easily visualized by direct transmission electron microscopy (Fig. 2). Like other acidic calcium stores, some acidocalcisomes possess a vacuolar proton ATPase (V-ATPase) in place or in addition to a VPPase to maintain an acidic $\mathrm{pH}$ typically 5-5.5 [6]. Acidocalcisomes contain high concentrations of calcium, at millimolar levels, and serve several functions, including storage of cations and phosphorus, polyphosphate metabolism, maintenance of intracellular $\mathrm{pH}$ homeostasis and osmoregulation [6]. Silencing of the TbPMC1 gene in Trypanosoma brucei, which encodes a $\mathrm{Ca}^{2+}$-ATPase pump localized to the acidocalcisome, results in reduced mobilizable calcium from these stores and is associated with impaired growth [7]. Deletion of the corresponding gene in Toxoplasma gondii ( $\mathrm{TgAl}$ ) also affects growth and has dramatic affects on invasion and virulence [8]. These findings underscore the physiological importance of calcium uptake into acidocalcisomes for their normal functioning. Calcium permeable channels located on acidocalcisomes however have yet to be identified.

\section{Vacuoles}

The contractile vacuole present in protists and slime molds is closely related to the acidocalcisome [6]. Both organelles are rich in calcium and polyphosphate and, in Trypanosoma cruzi, they are functionally linked as evidenced by the translocation of an aquaporin channel from acidocalcisomes to the contractile vacuole during regulatory volume decrease after hyposmotic stress [6]. Yeast vacuoles and the storage and lytic vacuoles in plants also share many similarities with acidocalcisomes, such as the presence of several pumps ( $\mathrm{V}$ ATPase, V-PPase, $\mathrm{Ca}^{2+}$-ATPase), exchangers $\left(\mathrm{Na}^{+} / \mathrm{H}^{+}, \mathrm{Ca}^{2+} / \mathrm{H}^{+}\right)$, and aquaporin [6].

Importantly vacuoles in both yeast [9] and plants [10] are the major site of intracellular $\mathrm{Ca}^{2+}$ storage. In support, deletion of vacuolar calcium ATPase pumps in both Dictyostelium [11] and yeast [12] renders the cells less tolerant to high extracellular calcium concentrations. Interestingly, transcripts for ACA4, a vacuolar $\mathrm{Ca}^{2+}$-ATPase from Arabidopsis, are present at increased levels during salt stress and provide salt tolerance when heterologously expressed in yeast [13]. Salt stress is associated with aberrant calcium signaling [14]. Thus, uptake of calcium into the vacuole might serve to temper these changes.

Genetic manipulation of the vacuolar channels TRPY1 in yeast and TPCs in plants has provided much insight into the role of vacuolar calcium release in the regulation of cell function. Both channels have been implicated in mediating calcium signals in response to hyperosmotic stress 
$[15,16]$. Several additional roles for plant TPCs have been identified including germination and stomatal movement [17]. Release of acidic calcium stores in yeast and plants is therefore vital for a variety of cellular processes.

\section{Endosomes and lysosomes}

The endolysosomal system of eukaryotes comprises many acidic organelles that contain variable amounts of calcium. Endosomes, once formed at the plasma membrane, become gradually acidified to a $\mathrm{pH}$ of $\sim 6$ as they mature. This change in $\mathrm{pH}$ is important for endosome function. For example it promotes the release of ligands from internalized receptors during receptor-mediated endocytosis. Given their origin, endosomes are expected to have the same free $\mathrm{Ca}^{2+}$ concentration within their interior as the extracellular fluid $(\sim 1 \mathrm{mM})$ after forming; however, there are few studies that have directly measured endosomal calcium levels. In 3T3 Swiss fibroblasts, calcium is apparently rapidly released from newly formed endosomes such that the luminal free concentration falls to $\sim 3 \mu \mathrm{M}$ within 20 minutes of formation [18]. Using similar methods, the concentration of calcium in enlarged endosome-like structures formed in pancreatic acinar cells stimulated with supramaximal concentrations of the brain-gut peptide cholecystokinin was recently reported to be higher at $\sim 40 \mu \mathrm{M}$ [19] but at the lower end of the free calcium concentration measured in the endoplasmic reticulum $(60-400 \mu \mathrm{M})$ [20]. Nevertheless, the lumenal endosomal calcium concentration is still at least an order of magnitude higher than resting cytosolic calcium levels. Thus, endosomes can also be considered acidic calcium stores, that are clearly mobile perhaps fuelling more restricted local changes in cytosolic calcium concentration.

Lysosomes are ubiquitous organelles that are highly acidic $(\mathrm{pH} 4-5)$ and which are responsible for the recycling of cellular constituents delivered by endocytic and autophagic routes. In addition to this well established role, there is currently a growing appreciation of these organelles as calcium stores. The presence of releasable $\mathrm{Ca}^{2+}$ in lysosomes has been demonstrated based on experiments using glycyl-L-phenylalanine-naphthylamide (GPN). GPN is a lysosome-disrupting cathepsin-C substrate that was originally used to distinguish lysosomes, which contain cathepsin $\mathrm{C}$, from prelysosomal endocytic vacuoles, which do not [21]. Hydrolysis of GPN by cathepsin C induces osmotic swelling of the lysosome and release of its content, including $\mathrm{Ca}^{2+}$, into the cytoplasm. Indeed, GPN induces increases in cytosolic calcium concentration when applied to a variety of different cells including MDCK cells [22]. Figure 3 highlights the presence of GPN-sensitive calcium stores in neurons. Direct measurement of luminal calcium concentration of lysosomes is difficult given the harsh acidic and proteolytic environment. Nevertheless, carefully controlled experiments in macrophages [23] and more recently fibroblasts [24] using internalized fluorescent indicators indicate that the average free calcium concentration in lysosomes is approximately $500 \mu \mathrm{M}$ and thus comparable to the concentration within the endoplasmic reticulum [20].

A multitude of hormones and neurotransmitters evoke changes in cytosolic calcium through production of calcium-mobilizing messengers that, in turn, mobilize intracellular calcium stores [1]. Although this process is generally ascribed to inositol trisphosphate or cyclic ADPribose which both mobilize endoplasmic reticulum calcium stores, much evidence indicates an additional critical role for NAADP (Box 3). Importantly, as first shown in the sea urchin egg [25], NAADP-mediated calcium signals are blocked by GPN indicating that NAADP mobilizes calcium from lysosomes or lysosome-like compartments [26]. NAADP is also likely to release calcium from endosomes [27]. Thus, the endo-lysosomal system serves as a bonafide mobilizable calcium store. 


\section{Box 3}

\section{NAADP}

NAADP is the newest and most potent of the calcium-mobilizing messengers [26] (Figure III). In sea urchin eggs, where the calcium-mobilizing ability of NAADP was first discovered [103], the pharmacology of NAADP-induced calcium release and the biochemical properties of the binding protein are very distinct from established endoplasmic reticulum calcium channels, indicative of a novel channel [103,104]. Moreover, Churchill and colleagues identified the target calcium stores as lysosome-like by showing selective block of NAADP-mediated calcium signals by the lysomotropic agent GPN and also by bafilomycin- $A_{1}$ [25]. The latter is an inhibitor of V-type ATPases, which by collapsing the $\mathrm{pH}$ gradient across the membrane of the acidic store, probably prevents calcium uptake. Thus, unlike inositol trisphosphate and cyclic ADP-ribose, which generally mobilize endoplasmic reticulum calcium stores through well-characterized channels (but see Box 2), NAADP appears highly unusual in activating channels located on acidic calcium stores. These include endosomes [27], lysosomes [105], lysosome-related organelles [25] and secretory granules [40]. Although, the molecular identity of the channel is subject to debate, several extracellular cues that elevate cytosolic calcium levels do so through raising cellular NAADP levels. These range from egg jelly acting on sea urchin sperm cells [106] to the neurotransmitter glutamate acting on mammalian brain slices [107]. Intriguingly, NAADPsensitive calcium channels rarely operate in isolation. Instead, current evidence suggests that, upon generation, NAADP initially evokes a relatively small trigger [108] release of calcium from acidic calcium stores, which in turn sensitizes neighbouring channels on the endoplasmic reticulum to mediate larger calcium signals by calcium-induced calcium release [26] (Fig. III). Importantly, this chatter [109] between NAADP-sensitive acidic calcium stores and other calcium sources has been implicated in a variety of cellular processes ranging from fertilization [106,110] to neuronal differentiation [111]. At present, this pathway represents the best-characterized pathway for calcium release from acidic calcium stores in animal cells. NAADP signaling has also been described in plants [112] but not in micro-organisms. Gross, in a recent insightful review [113], has proposed that functional cross-talk between acidic calcium stores and the endoplasmic reticulum may underlie differentiation in Dictyostelium. It is tempting to speculate that this may involve NAADP particularly given the presence of the two-pore channel, a strong candidate NAADP target (see main text) in this organism.

\section{Lysosome-related organelles}

Lysosome-related organelles, often referred to as secretory lysosomes, are a heterogeneous group of organelles that can be defined as sharing some physiological features with lysosomes $[28,29]$. Such organelles include melanosomes, lytic granules of lymphocytes, major histocompatibility complex class II compartments of antigen-presenting cells (dendritic cells, B lymphocytes and macrophages), platelet dense granules, basophilic granules, neutrophil azurophil granules [28], and, possibly, others such as platelet alpha granules, lamellar bodies of the lung, osteoclast granules, pigment granules of Drosophila, the fat storage organelle of the nematode Caenorhabditis elegans, Weibel-Palade bodies of endothelial cells, acrosomes from sperm and inhibitory lysosomes from dendritic cells [29]. Many lysosome-related organelles are acidic and rich in calcium. Platelet dense granules for example maintain a pH of $\sim 5.4$ and a total calcium concentration of $2.2 \mathrm{M}$ [30]. These organelles are especially interesting acidic stores because they resemble acidocalcisomes in that they contain polyphosphate and are electron dense when examined by direct transmission electron microscopy without staining [31]. In addition, acidocalcisomes and platelet dense granules appear to share the system for targeting of their membrane proteins through adaptor protein 3 
[32]. This led to the proposal that acidocalcisomes are conserved from bacteria to man and that other acidocalcisome-like organelles are likely present in different organisms [6]. Indeed, acidocalcisome-like organelles have also been found recently in insect [33] and sea urchin eggs (Ramos, I.B. et al., unpublished observation).

\section{Secretory vesicles and the Golgi complex}

Finally, the acidic compartments of the secretory pathway also contain substantial levels of calcium. $\mathrm{Ca}^{2+}$ is highly abundant in secretory granules of many secretory cell types and the related synaptic vesicles of neurons. Remarkably, some secretory granules such as those in adrenal chromaffin cells contain 20-40 $\mathrm{mM}$ total calcium [34] and are therefore a major store of calcium. Free $\mathrm{Ca}^{2+}$ in secretory granules has been measured between 50-100 $\mu \mathrm{M}$ [35]. Secretory granules in both pancreatic beta cells [36]. and adrenal chromafin cells [37] take up calcium upon secretagogue stimulation. This process might serve to moderate cytosolic calcium similar to uptake of $\mathrm{Ca}^{2+}$ by vacuoles (see above). Thus, like the endoplasmic reticulum, acidic calcium stores may function as calcium "sinks" as well as calcium sources.

Notably, total calcium concentration in the Golgi has been estimated to be more than $10 \mathrm{mM}$ in neurosecretory PC12 cells [38]. The free $\mathrm{Ca}^{2+}$ is measured between $300 \mu \mathrm{M}$ to $1.4 \mathrm{mM}$ in HeLa cells [39] and therefore similar, if not higher than the concentration of calcium within the endoplasmic reticulum. Thus, although less acidic than the other organelles discussed $(\mathrm{pH}$ 6.6), the Golgi apparatus can also be considered an acidic calcium store.

The possible presence of inositol trisphosphate/ryanodine receptors on secretory granules and the Golgi complex (Box 2) suggests that mobilisation of these stores might contribute to cytosolic calcium signals upon receptor-mediated production of inositol trisphosphate and cyclic ADP-ribose or through calcium-induced calcium release stimulated by other routes. NAADP may also be involved given the presence of the target channels on secretory granules [40]. The localization of calcium release channels on secretory organelles is particularly interesting as generation of local calcium signals close to the calcium-dependent fusion machinery might in part drive secretion. Alternatively, it is possible that calcium within these organelles may serve functional roles in the extracellular space upon its secretion.

\section{Mechanisms of calcium release from acidic calcium stores: New players}

TRPMs and TRPVs belong to the group 1 TRP subfamily [41]. TRPM2 is an unusual protein in that it is a so-called chanzyme, possessing both ion channel and enzymatic (ADPR pyrophosphatase) activity [41]. Electrophysiological analysis indicates that TRPM2 is nonselective cation channel permeable to calcium that is activated by cytosolic ADP-ribose and a variety of other factors including hydrogen peroxide [41]. Like other TRPMs it is localized to the plasma membrane to mediate calcium influx [41]. However, a recent intriguing report has localized the protein to the lysosome, where it functions as a calcium release channel mediating cell death in response to oxidative stress [42]. The reported sensitivity of TRPM2 to NAADP [43] might also suggest an involvement in NAADP-mediated mobilization of lysosomal calcium stores [44]. TRPV2, in common with several other TRPV members, is activated by heat [41]. Proteomic analysis has revealed the presence of TRPV2 on early endosomes [45]. Indeed a channel with the biophysical properties similar to those of TRPV2 has been identified electrophysiologically on enlarged endosomes [46]. Thus, TRPV2, like TRPM2, shows a dual distribution on the cell surface and within acidic calcium stores and might therefore mediate both calcium influx and calcium release. Alternatively, the intracellular location could reflect trafficking of these channels to and from the plasma membrane.

Two-pore channels, as discussed previously (Box 2), have been most extensively studied in plants. In a series of recent independent studies, direct molecular evidence has been obtained 
indicating that, in animals, the two-pore channel is the target for NAADP. Human TPC1 was shown to localize to both endosomes and lysosomes [47,48], whereas human and rodent TPC2 were shown to be predominantly lysosomal [47-49], consistent with the vacuolar location of plant TPCs [17]. Importantly, over-expression of TPC 1 and TPC 2 enhanced NAADP-mediated calcium signals [47-49]. Conversely, siRNA-mediated knockdown of TPC1 attenuated NAADP-mediated calcium signals in human SKBR3 cells [47]. Additionally, NAADPdependent plasma membrane currents in pancreatic beta cells from TPC 2 knockout mice were absent [48]. Finally, mutation of a single conserved residue within a putative pore region was sufficient to prevent calcium release by TPC1 and revealed dominant-negative activity [47]. Taken together, these studies identify this ubiquitous yet poorly characterized family of ion channels as credible targets for NAADP, providing a molecular basis for calcium release from acidic stores by this messenger. Like TRP channels (Box 2), TPCs are widely distributed in mammalian cells [47-49], indicating that they too might play a general role in the mobilisation of acidic calcium stores.

Comparative genomic analysis indicates the presence of two-pore channels throughout the animal kingdom. However, these channels are notably absent in certain organisms including flies (D. melanogaster) and nematode worms (C. elegans). Most deuterostomes however, possess three genes. In the sea urchin, a basal deuterostome and extensively used model system for the study of NAADP-mediated calcium signaling, all three isoforms have been cloned and characterized [50]. Like mammalian TPCs, sea urchin TPCs localize to acidic organelles and enhance NAADP-mediated calcium signals when overexpressed [50]. Intriguingly, although the full TPC gene complement is found in Laurasiatherian mammals (such as dogs and cows), the TPC 3 gene appears to be absent from certain mammals (such as rats and humans) that belong to the closely related sister group, Euarchontoglires. Moreover, evidence for a TPC3 pseudogene has been provided in the primate lineage [50]. Thus, degeneration of TPC3 is a rare, relatively recent and on-going event likely indicative of relaxed selection pressure. Further comparative genomics and physiology will no doubt provide clues to the functional role of TPC3.

P2X receptors are ligand-gated non-selective cation channels regulated by extracellular ATP. In Dictyostelium, a P2X receptor homologue has been identified and localized to the contractile vacuole where it was shown to be involved in osmoregulation [51]. How the channel with its ligand binding site facing the vacuole lumen in this location would access ATP is not clear but it is possible that ATP is imported from the cytosol where it is present at millimolar levels. Recent studies in mammalian cells also place rat P2X4 receptors within lysosomes where they resist degradation by virtue of their $\mathrm{N}$-linked glycans [52]. Prior stimulation of cells with agents that promote lysosome secretion was shown to increase subsequent channel activity at the plasma membrane. Thus, in this case the lysosomal location of a calcium permeable channel probably reflects its transit to its ultimate destination. However, that lysosomes contain ATP might suggest hitherto unsuspected intracellular roles, such as in phagocytosis [52], for this traditionally viewed cell surface channel.

\section{Mechanisms of calcium buffering within acidic calcium stores}

The available information concerning how calcium is buffered in acidic compartments is at present limited. Most of the calcium present in acidic stores is likely bound to polyanionic matrixes. Notably, polyphosphate is present in many acidic calcium stores such as acidocalcisomes of different organisms [6], the yeast vacuole [53] and probably lysosomes [54] and lysosome-related organelles [31]. Polyphosphate is a linear polymer of inorganic phosphate moieties, from a few to several hundred, linked by high-energy phosphoanhydride bonds [55]. It is capable of binding calcium and other cations and basic organic molecules, such as basic amino acids, in a semicrystalline state. This is revealed by magic-angle spinning 
NMR detection of solid-state condensed phosphate and the high electron density of acidocalcisomes in situ [6]. Evidence for association of calcium with polyphosphate comes from experiments showing that alkalinization of acidocalcisomes led to $\mathrm{Ca}^{2+}$ release and hydrolysis of polyphosphate in a number of cells [6]. Polyphosphate might therefore represent the major $\mathrm{Ca}^{2+}$ buffer present in acidic calcium stores.

Oxalates likely play a similar $\mathrm{Ca}^{2+}$ buffering role in plants. Oxalates are abundant in the plant vacuole where they precipitate calcium, forming crystals [56]. In animal cells, other polyanions such as heparin present in basophilic granules [57], or mucin present in mucinogen granules of Goblet cells [58], might also buffer intragranular calcium, but there is little information about their physiological role. Finally, lumenal proteins might also contribute to calcium buffering in lysosome-related organelles and secretory granules. Melanosomes, for example are rich in melanin, a $\mathrm{Ca}^{2+}$-binding protein [59]. It has been found that melanocytes richest in melanin are able to accumulate more $\mathrm{Ca}^{2+}$ and buffer cytosolic $\mathrm{Ca}^{2+}$ changes better than those possessing less melanin [59]. The granins present in neurosecretory granules are probably the best-characterized proteins present in acidic calcium stores with respect to their $\mathrm{Ca}^{2+}$-binding properties. They bind to calcium with low affinity and high capacity, a property that allow them to form aggregates at low $\mathrm{pH}$ in the presence of calcium [60]. The presence of buffering mechanisms within acidic calcium stores is consistent with their role as mobilizable calcium stores.

\section{Dysfunction of acidic calcium stores}

Many diseases result from deregulated calcium signalling. With appropriate means to fill with, buffer and release calcium, it is perhaps not surprising that dysfunction of acidic calcium stores is also linked with certain diseases.

The endolysosomal system and the secretory pathway are highly dynamic structures in which membrane fusion between vesicles is crucial for correct functioning. The role of calcium in stimulating membrane fusion is well established in the process of regulated secretion. Calcium might also play crucial roles in so-called constitutive fusion events, which are traditionally thought of as being calcium independent. Fusion in vitro of yeast vacuoles [61], early endosomes from rat PC12 cells [62], late-endosome-lysosomes from rat liver [63] and Golgi vesicles from rat brain [64] is inhibited by chelating extra-vesicular calcium. Chelating luminal calcium also blocks fusion [62] suggesting that calcium release from the acidic calcium store is required for fusion. Interestingly, in all of the above cases, inhibition of fusion is readily observed with the calcium chelator BAPTA but not with EGTA. Although both chelators bind to calcium with similar affinity, the former does so more rapidly [65]. Such differential sensitivity to BAPTA and EGTA suggests that the calcium signal must be localized very close to the putative sensor thus evading buffering by the slower chelator. The nature of the calcium channel(s) responsible for this local release of calcium however is not known. A strong candidate is TRPML1 as cells derived from mucolipidosis IV sufferers (who posses a defective TRPML1 gene) display disrupted trafficking within the endo-lysosomal system [66], consistent with impaired fusion. A similar phenotype is observed in worms deficient in the TRPML homologue, CUP5 [67]. Direct evidence for a role for TRPML in the release of calcium that regulates membrane fusion, however, is currently lacking.

As discussed above, the two-pore channels have recently emerged as the likely targets for NAADP in animal cells [47-50]. As research into animal TPCs is only in its infancy, functional roles for this protein downstream of calcium signalling have yet to be identified. Coding variants in TPC2 have however been associated with hair pigmentation traits [68]. These findings potentially link pigmentation to NAADP-mediated calcium signals. Interestingly, a gain-of-function mutation in the endo-lysosomal calcium channel TRPML3 that causes the 
mouse Varitint-Waddler phenotype also affects pigmentation (coat colour) [69] consistent with a role for lysosomal calcium release in regulating pigmentation. Indeed, pigmentation defects are common in several lysosomal storage diseases [70], perhaps as a consequence of altered calcium signalling through lysosomes or lysosome-related organelles secondary to dysfunction of the lysosomal target [24]. Notably, a coding variant in NCKX5, a melanosomal/Golgi calcium exchanger also correlates with changes in skin pigmentation in fish and humans [71].

Finally, altered calcium signaling through acidic calcium stores in the pancreas and skin have also been linked to disease. Acute pancreatitis is characterized by inappropriate activation of proteases in pancreatic acinar cells. This can be induced by excessive alcohol consumption. Recent studies have shown that fatty acid ethyl esters (alcohol metabolites) activate inositol trisphosphate receptors on both acidic stores within the secretory pole and in the ER [72]. Only the former however resulted in intracellular protease activation suggesting that their mobilisation might specifically contribute to disease progression [72]. Deletion of the PMR1 gene in yeast, which encodes a calcium ATPase localized to the Golgi [73], impairs Golgi functions such as proteolytic processing and protein glycosylation [74] and is associated with elevated cytosolic calcium levels [75]. Notably, mutation of the orthologous gene in humans (SPCA1) results in the blistering skin disorder Hailey-Hailey disease [76]. Cytosolic calcium levels are also elevated in this disease [76] and Golgi luminal calcium concentration reduced [77]. These findings underscore the importance of calcium uptake into this acidic store for both proper functioning of the organelle and in the maintenance of cytosolic calcium homeostasis.

\section{Future perspectives}

We have argued that acidic calcium stores are present in probably all organisms. They differ significantly in their form and can coexist in the same cell. It is clear that acidic calcium stores can accumulate vast levels of calcium, although measurements of the free (mobilizable) concentration of calcium are scant and should be the focus of future studies. Much progress has been made in identifying the calcium pumps/exchangers and calcium-permeable channels present on these stores with clear physiological roles for calcium uptake into acidocalcisomes, both calcium uptake and $\mathrm{Ca}^{2+}$ release from the vacuoles of yeast and plants and for NAADPmediated calcium release from lysosomes and lysosome-related organelles in animals.

However there are still gaps in our knowledge with respect to the calcium channel complement of acidocalcisomes, the uptake machinery of the endo-lysosomal system and in general how calcium is buffered within these organelles. A comprehensive molecular description of the calcium signaling "tool kit" for these organelles is required. This is probably forthcoming in the near future as advances in organelle proteomics continue but one needs to consider that the presence of calcium channels in an acidic calcium store need not necessarily equate to a functional role at this location and could, in some cases, reflect their trafficking. Future studies might also consider the issue whether the presence of calcium within a given acidic store may regulate luminal processes perhaps dynamically as calcium is sequestered and released. All of these questions are deserving of answer as we now begin to associate defective calcium handling by acidic calcium stores with disease.

\section{Acknowledgments}

We thank Manfredo Seufferheld and George Dickinson for the data provided in Figures 2 and 3, and Chi Li and Silvia N.J. Moreno for useful discussions. Work in SP's laboratory was supported by the Biotechnology and Biological Sciences Research Council (grant BB/G013721/1) and grants from the Alzheimer's Research Trust and Research into Ageing. Work in R.D. s laboratory was supported by U.S. National Institutes of Health grants AI-068647 and AI-077538. 


\section{References}

1. Berridge MJ, Lipp P, Bootman MD. The versatility and universality of calcium signalling. Nat Rev Mol Cell Biol 2000;1:11-21. [PubMed: 11413485]

2. Orrenius S, Zhivotovsky B, Nicotera P. Regulation of cell death: the calcium-apoptosis link. Nat Rev Mol Cell Biol 2003;4:552-565. [PubMed: 12838338]

3. Clapham DE. Calcium signaling. Cell 2007;131:1047-1058. [PubMed: 18083096]

4. Berridge MJ. The endoplasmic reticulum: a multifunctional signaling organelle. Cell Calcium 2002;32:235-249. [PubMed: 12543086]

5. Pozzan T, Rizzuto R, Volpe P, Meldolesi J. Molecular and cellular physiology of intracellular calcium stores. Physiol Rev 1994;74:595-636. [PubMed: 8036248]

6. Docampo R, de Souza W, Miranda K, Rohloff P, Moreno SN. Acidocalcisomes - conserved from bacteria to man. Nat Rev Microbiol 2005;3:251-261. [PubMed: 15738951]

7. Luo S, Rohloff P, Cox J, Uyemura SA, Docampo R. Trypanosoma brucei plasma membrane-type $\mathrm{Ca}^{2+}$-ATPase 1 (TbPMC1) and 2 (TbPMC2) genes encode functional $\mathrm{Ca}^{2+}$-ATPases localized to the acidocalcisomes and plasma membrane, and essential for $\mathrm{Ca}^{2+}$ homeostasis and growth. J Biol Chem 2004;279:14427-14439. [PubMed: 14724285]

8. Luo S, Ruiz FA, Moreno SN. The acidocalcisome $\mathrm{Ca}^{2+}$-ATPase (TgA1) of Toxoplasma gondii is required for polyphosphate storage, intracellular calcium homeostasis and virulence. Mol Microbiol 2005;55:1034-1045. [PubMed: 15686552]

9. Cunningham KW, Fink GR. $\mathrm{Ca}^{2+}$ transport in Saccharomyces cerevisiae. J Exp Biol 1994;196:157166. [PubMed: 7823019]

10. Martinoia E, Maeshima M, Neuhaus HE. Vacuolar transporters and their essential role in plant metabolism. J Exp Bot 2007;58:83-102. [PubMed: 17110589]

11. Moniakis J, Coukell MB, Janiec A. Involvement of the $\mathrm{Ca}^{2+}$-ATPase PAT1 and the contractile vacuole in calcium regulation in Dictyostelium discoideum. J Cell Sci 1999;112:405-414. [PubMed: 9885293]

12. Cunningham KW, Fink GR. Calcineurin-dependent growth control in Saccharomyces cerevisiae mutants lacking PMC1, a homolog of plasma membrane $\mathrm{Ca}^{2+}$ ATPases. J Cell Biol 1994;124:351363. [PubMed: 7507493]

13. Geisler M, Frangne N, Gomes E, Martinoia E, Palmgren MG. The ACA4 gene of Arabidopsis encodes a vacuolar membrane calcium pump that improves salt tolerance in yeast. Plant Physiol 2000;124:1814-1827. [PubMed: 11115896]

14. Niu X, Bressan RA, Hasegawa PM, Pardo JM. Ion Homeostasis in NaCl Stress Environments. Plant Physiol 1995;109:735-742. [PubMed: 12228628]

15. Denis V, Cyert MS. Internal $\mathrm{Ca}^{2+}$ release in yeast is triggered by hypertonic shock and mediated by a TRP channel homologue. J Cell Biol 2002;156:29-34. [PubMed: 11781332]

16. Furuichi T, Cunningham KW, Muto S. A putative two pore channel AtTPC1 mediates $\mathrm{Ca}^{2+}$ flux in Arabidopsis leaf cells. Plant Cell Physiol 2001;42:900-905. [PubMed: 11577183]

17. Peiter E, Maathuis FJ, Mills LN, Knight H, Pelloux J, Hetherington AM, Sanders D. The vacuolar $\mathrm{Ca}^{2+}$-activated channel TPC1 regulates germination and stomatal movement. Nature 2005;434:404408. [PubMed: 15772667]

18. Gerasimenko JV, Tepikin AV, Petersen OH, Gerasimenko OV. Calcium uptake via endocytosis with rapid release from acidifying endosomes. Curr Biol 1998;8:1335-1338. [PubMed: 9843688]

19. Sherwood MW, Prior IA, Voronina SG, Barrow SL, Woodsmith JD, Gerasimenko OV, Petersen OH, Tepikin AV. Activation of trypsinogen in large endocytic vacuoles of pancreatic acinar cells. Proc Natl Acad Sci U S A 2007;104:5674-5679. [PubMed: 17363470]

20. Miyawaki A, llopis J, Heim R, McCaffery JM, Adams JA, Tsien RY. Fluorescent indicators for $\mathrm{Ca}^{2+}$ based on green fluorescent proteins and calmodulin. Nature 1997;388:882-887. [PubMed: 9278050]

21. Berg TO, Stromhaug E, Lovdal T, Seglen O, Berg T. Use of glycyl-L-phenylalanine 2-naphthylamide, a lysosome-disrupting cathepsin $\mathrm{C}$ substrate, to distinguish between lysosomes and prelysosomal endocytic vacuoles. Biochem J 1994;300:229-236. [PubMed: 8198538] 
22. Haller T, Dietl P, Deetjen P, Volkl H. The lysosomal compartment as intracellular calcium store in MDCK cells: a possible involvement in $\mathrm{InsP}_{3}$-mediated $\mathrm{Ca}^{2+}$ release. Cell Calcium 1996;19:157165. [PubMed: 8689673]

23. Christensen KA, Myers JT, Swanson JA. pH-dependent regulation of lysosomal calcium in macrophages. J Cell Sci 2002;115:599-607. [PubMed: 11861766]

24. Lloyd-Evans E, Morgan AJ, He X, Smith DA, Elliot-Smith E, Sillence DJ, Churchill GC, Schuchman $\mathrm{EH}$, Galione A, Platt FM. Niemann-Pick disease type $\mathrm{C} 1$ is a sphingosine storage disease that causes deregulation of lysosomal calcium. Nat Med 2008;14:1247-1255. [PubMed: 18953351]

25. Churchill GC, Okada Y, Thomas JM, Genazzani AA, Patel S, Galione A. NAADP mobilizes Ca ${ }^{2+}$ from reserve granules, lysosome-related organelles, in sea urchin eggs. Cell 2002;111:703-708. [PubMed: 12464181]

26. Guse AH, Lee HC. NAADP: a universal $\mathrm{Ca}^{2+}$ trigger. Sci Signal 2008;1:re10. [PubMed: 18984909]

27. Menteyne A, Burdakov A, Charpentier G, Petersen OH, Cancela JM. Generation of specific $\mathrm{Ca}^{2+}$ signals from $\mathrm{Ca}^{2+}$ stores and endocytosis by differential coupling to messengers. Curr Biol 2006;16:1931-1937. [PubMed: 17027490]

28. Dell'Angelica EC, Mullins C, Caplan S, Bonifacino JS. Lysosome-related organelles. FASEB J 2000;14:1265-1278. [PubMed: 10877819]

29. Raposo G, Marks MS, Cutler DF. Lysosome-related organelles: driving post-Golgi compartments into specialisation. Curr Opin Cell Biol 2007;19:394-401. [PubMed: 17628466]

30. Holmsen H, Weiss HJ. Secretable storage pools in platelets. Annu Rev Med 1979;30:119-134. [PubMed: 233610]

31. Ruiz FA, Lea CR, Oldfield E, Docampo R. Human platelet dense granules contain polyphosphate and are similar to acidocalcisomes of bacteria and unicellular eukaryotes. J Biol Chem 2004;279:44250-44257. [PubMed: 15308650]

32. Moreno SN, Docampo R. The role of acidocalcisomes in parasitic protists. J Euk Microbiol 2009;56:208-213. [PubMed: 19527347]

33. Motta LS, Ramos IB, Gomes FM, de Souza W, Champagne DE, Santiago MF, Docampo R, Miranda $\mathrm{K}$, Machado EA. Proton-pyrophosphatase and polyphosphate in acidocalcisome-like vesicles from oocytes and eggs of Periplaneta americana. Insect Biochem Mol Biol 2009;39:198-206. [PubMed: 19111615]

34. Yoo SH. Secretory granules in inositol 1,4,5-trisphosphate-dependent $\mathrm{Ca}^{2+}$ signaling in the cytoplasm of neuroendocrine cells. FASEB J. 2009 (in press).

35. Santodomingo J, Vay L, Camacho M, Hernandez-Sanmiguel E, Fonteriz RI, Lobaton CD, Montero M, Moreno A, Alvarez J. Calcium dynamics in bovine adrenal medulla chromaffin cell secretory granules. Eur J Neurosci 2008;28:1265-1274. [PubMed: 18973554]

36. Mitchell KJ, Pinton P, Varadi A, Tacchetti C, Ainscow EK, Pozzan T, Rizzuto R, Rutter GA. Dense core secretory vesicles revealed as a dynamic $\mathrm{Ca}^{2+}$ store in neuroendocrine cells with a vesicleassociated membrane protein aequorin chimaera. J Cell Biol 2001;155:41-51. [PubMed: 11571310]

37. Mahapatra NR, Mahata M, Hazra PP, McDonough PM, O'Connor DT, Mahata SK. A dynamic pool of calcium in catecholamine storage vesicles. Exploration in living cells by a novel vesicle-targeted chromogranin A-aequorin chimeric photoprotein. J Biol Chem 2004;279:51107-51121. [PubMed: 15358782]

38. Pezzati R, Bossi M, Podini P, Meldolesi J, Grohovaz F. High-resolution calcium mapping of the endoplasmic reticulum-Golgi-exocytic membrane system. Electron energy loss imaging analysis of quick frozen-freeze dried PC12 cells. Mol Biol Cell 1997;8:1501-1512. [PubMed: 9285821]

39. Pinton P, Pozzan T, Rizzuto R. The Golgi apparatus is an inositol 1,4,5-trisphosphate-sensitive $\mathrm{Ca}^{2}$ ${ }^{+}$store, with functional properties distinct from those of the endoplasmic reticulum. EMBO J 1998;17:5298-5308. [PubMed: 9736609]

40. Mitchell KJ, Lai FA, Rutter GA. Ryanodine receptor type I and nicotinic acid adenine dinucleotide phosphate (NAADP) receptors mediate $\mathrm{Ca}^{2+}$ release from insulin-containing vesicles in living pancreatic $\beta$-cells (MIN6). J Biol Chem 2003;278:11057-11064. [PubMed: 12538591]

41. Venkatachalam K, Montell C. TRP channels. Annu Rev Biochem 2007;76:387-417. [PubMed: 17579562] 
42. Lange I, Yamamoto S, Partida-Sanchez S, Mori Y, Fleig A, Penner R. TRPM2 functions as a lysosomal $\mathrm{Ca}^{2+}$-release channel in beta cells. SciSignal 2009;2:ra23.

43. Beck A, Kolisek M, Bagley LA, Fleig A, Penner R. Nicotinic acid adenine dinucleotide phosphate and cyclic ADP-ribose regulate TRPM2 channels in T lymphocytes. FASEB J 2006;20:962-964. [PubMed: 16585058]

44. Patel S, Docampo R. In with the TRP channels: intracellular functions for TRPM1 and TRPM2. Sci Signal 2009;2:pe69. [PubMed: 19887679]

45. Wainszelbaum MJ, Proctor BM, Pontow SE, Stahl PD, Barbieri MA. IL4/PGE2 induction of an enlarged early endosomal compartment in mouse macrophages is Rab5-dependent. Exp Cell Res 2006;312:2238-2251. [PubMed: 16650848]

46. Saito M, Hanson PI, Schlesinger P. Luminal chloride-dependent activation of endosome calcium channels: patch clamp study of enlarged endosomes. J Biol Chem 2007;282:27327-27333. [PubMed: 17609211]

47. Brailoiu E, Churamani D, Cai X, Schrlau MG, Brailoiu GC, Gao X, Hooper R, Boulware MJ, Dun NJ, Marchant JS, Patel S. Essential requirement for two-pore channel 1 in NAADP-mediated calcium signaling. J Cell Biol 2009;186:201-209. [PubMed: 19620632]

48. Calcraft PJ, Ruas M, Pan Z, Cheng X, Arredouani A, Hao X, Tang J, Rietdorf K, Teboul L, Chuang KT, Lin P, Xiao R, Wang C, Zhu Y, Lin Y, Wyatt CN, Parrington J, Ma J, Evans AM, Galione A, Zhu MX. NAADP mobilizes calcium from acidic organelles through two-pore channels. Nature 2009;459:596-600. [PubMed: 19387438]

49. Zong X, Schieder M, Cuny H, Fenske S, Gruner C, Rotzer K, Griesbeck O, Harz H, Biel M, WahlSchott C. The two-pore channel TPCN2 mediates NAADP-dependent $\mathrm{Ca}^{2+}$-release from lysosomal stores. Pflugers Arch 2009;458:891-899. [PubMed: 19557428]

50. Brailoiu E, Hooper R, Cai X, Brailoiu GC, Keebler MV, Dun NJ, Marchant JS, Patel S. An ancestral deuterostome family of two-pore channels mediates nicotinic acid adenine dinucleotide phosphatedependent calcium release from acidic organelles. J Biol Chem 2010;285:2897-2901. [PubMed: 19940116]

51. Fountain SJ, Parkinson K, Young MT, Cao L, Thompson CR, North RA. An intracellular P2X receptor required for osmoregulation in Dictyostelium discoideum. Nature 2007;448:200-203. [PubMed: 17625565]

52. Qureshi OS, Paramasivam A, Yu JC, Murrell-Lagnado RD. Regulation of P2X4 receptors by lysosomal targeting, glycan protection and exocytosis. J Cell Sci 2007;120:3838-3849. [PubMed: 17940064]

53. Kulaev IS, Vagabov VM. Polyphosphate metabolism in micro-organisms. Adv Microb Physiol 1983;24:83-171. [PubMed: 6320606]

54. Pisoni RL, Lindley ER. Incorporation of $\left[{ }^{32} \mathrm{P}\right]$ orthophosphate into long chains of inorganic polyphosphate within lysosomes of human fibroblasts. J Biol Chem 1992;267:3626-3631. [PubMed: 1740414]

55. Kornberg A. Inorganic polyphosphate: toward making a forgotten polymer unforgettable. J Bacteriol 1995;177:491-496. [PubMed: 7836277]

56. Franceschi VR, Nakata PA. Calcium oxalate in plants: formation and function. Annu Rev Plant Biol 2005;56:41-71. [PubMed: 15862089]

57. Kendall MD, Warley A. Elemental content of mast cell granules measured by X-ray microanalysis of rat thymic tissue sections. J Cell Sci 1986;83:77-87. [PubMed: 3805147]

58. Nguyen T, Chin WC, Verdugo P. Role of $\mathrm{Ca}^{2+} / \mathrm{K}^{+}$ion exchange in intracellular storage and release of $\mathrm{Ca}^{2+}$ Nature 1998;395:908-912. [PubMed: 9804425]

59. Hoogduijn MJ, Smit NP, van der Laarse A, van Nieuwpoort AF, Wood JM, Thody AJ. Melanin has a role in $\mathrm{Ca}^{2+}$ homeostasis in human melanocytes. Pigment Cell Res 2003;16:127-132. [PubMed: 12622789]

60. Crivellato E, Nico B, Ribatti D. The chromaffin vesicle: advances in understanding the composition of a versatile, multifunctional secretory organelle. Anat Rec 2008;291:1587-1602.

61. Peters C, Mayer A. $\mathrm{Ca}^{2+} /$ calmodulin signals the completion of docking and triggers a late step of vacuole fusion. Nature 1998;396:575-580. [PubMed: 9859992] 
62. Holroyd C, Kistner U, Annaert W, Jahn R. Fusion of endosomes involved in synaptic vesicle recycling. Mol Biol Cell 1999;10:3035-3044. [PubMed: 10473644]

63. Pryor PR, Mullock BM, Bright NA, Gray SR, Luzio JP. The role of intraorganellar $\mathrm{Ca}^{2+}$ in late endosome-lysosome heterotypic fusion and in the reformation of lysosomes from hybrid organelles. J Cell Biol 2000;149:1053-1062. [PubMed: 10831609]

64. Porat A, Elazar Z. Regulation of intra-Golgi membrane transport by calcium. J Biol Chem 2000;275:29233-29237. [PubMed: 10871627]

65. Stern MD. Buffering of calcium in the vicinity of a channel pore. Cell Calcium 1992;13:183-192. [PubMed: 1315621]

66. Chen CS, Bach G, Pagano RE. Abnormal transport along the lysosomal pathway in mucolipidosis, type IV disease. Proc Natl Acad Sci U S A 1998;95:6373-6378. [PubMed: 9600972]

67. Fares H, Greenwald I. Regulation of endocytosis by CUP-5, the Caenorhabditis elegans mucolipin-1 homolog. Nat Genet 2001;28:64-68. [PubMed: 11326278]

68. Sulem P, Gudbjartsson DF, Stacey SN, Helgason A, Rafnar T, Jakobsdottir M, Steinberg S, Gudjonsson SA, Palsson A, Thorleifsson G, Palsson S, Sigurgeirsson B, Thorisdottir K, Ragnarsson R, Benediktsdottir KR, Aben KK, Vermeulen SH, Goldstein AM, Tucker MA, Kiemeney LA, Olafsson JH, Gulcher J, Kong A, Thorsteinsdottir U, Stefansson K. Two newly identified genetic determinants of pigmentation in Europeans. Nat Genet 2008;40:835-837. [PubMed: 18488028]

69. Cuajungco MP, Samie MA. The varitint-waddler mouse phenotypes and the TRPML3 ion channel mutation: cause and consequence. Pflugers Arch 2008;457:463-473. [PubMed: 18504603]

70. Spritz RA. Molecular genetics of the Hermansky-Pudlak and Chediak-Higashi syndromes. Platelets 1998;9:21-29. [PubMed: 16793741]

71. Lamason RL, Mohideen MA, Mest JR, Wong AC, Norton HL, Aros MC, Jurynec MJ, Mao X, Humphreville VR, Humbert JE, Sinha S, Moore JL, Jagadeeswaran P, Zhao W, Ning G, Makalowska I, McKeigue PM, O’Donnell D, Kittles R, Parra EJ, Mangini NJ, Grunwald DJ, Shriver MD, Canfield VA, Cheng KC. SLC24A5, a putative cation exchanger, affects pigmentation in zebrafish and humans. Science 2005;310:1782-1786. [PubMed: 16357253]

72. Gerasimenko JV, Lur G, Sherwood MW, Ebisui E, Tepikin AV, Mikoshiba K, Gerasimenko OV, Petersen $\mathrm{OH}$. Pancreatic protease activation by alcohol metabolite depends on $\mathrm{Ca}^{2+}$ release via acid store $\mathrm{IP}_{3}$ receptors. Proc Natl Acad Sci U S A 2009;106:10758-10763. [PubMed: 19528657]

73. Rudolph HK, Antebi A, Fink GR, Buckley CM, Dorman TE, LeVitre J, Davidow LS, Mao JI, Moir DT. The yeast secretory pathway is perturbed by mutations in PMR1, a member of a $\mathrm{Ca}^{2+}$ ATPase family. Cell 1989;58:133-145. [PubMed: 2526682]

74. Antebi A, Fink GR. The yeast $\mathrm{Ca}^{2+}$-ATPase homologue, PMR1, is required for normal Golgi function and localizes in a novel Golgi-like distribution. Mol Biol Cell 1992;3:633-654. [PubMed: 1379856]

75. Halachmi D, Eilam Y. Elevated cytosolic free $\mathrm{Ca}^{2+}$ concentrations and massive $\mathrm{Ca}^{2+}$ accumulation within vacuoles, in yeast mutant lacking PMR1, a homolog of $\mathrm{Ca}^{2+}$-ATPase. FEBS Lett 1996;392:194-200. [PubMed: 8772202]

76. Hu Z, Bonifas JM, Beech J, Bench G, Shigihara T, Ogawa H, Ikeda S, Mauro T, Epstein EH Jr. Mutations in ATP2C1, encoding a calcium pump, cause Hailey-Hailey disease. Nat Genet 2000;24:61-65. [PubMed: 10615129]

77. Behne MJ, Tu CL, Aronchik I, Epstein E, Bench G, Bikle DD, Pozzan T, Mauro TM. Human keratinocyte ATP2C1 localizes to the Golgi and controls Golgi $\mathrm{Ca}^{2+}$ stores. J Invest Dermatol 2003;121:688-694. [PubMed: 14632183]

78. Carafoli E, Brini M. Calcium pumps: structural basis for and mechanism of calcium transmembrane transport. Curr Opin Chem Biol 2000;4:152-161. [PubMed: 10742184]

79. Van BK, Dode L, Vanoevelen J, Callewaert G, De SH, Missiaen L, Parys JB, Raeymaekers L, Wuytack F. The $\mathrm{Ca}^{2+} / \mathrm{Mn}^{2+}$ pumps in the Golgi apparatus. Biochim Biophys Acta 2004;1742:103112. [PubMed: 15590060]

80. Geisler M, Axelsen KB, Harper JF, Palmgren MG. Molecular aspects of higher plant P-type $\mathrm{Ca}^{2+}$ ATPases. Biochim Biophys Acta 2000;1465:52-78. [PubMed: 10748247]

81. Missiaen L, Dode L, Vanoevelen J, Raeymaekers L, Wuytack F. Calcium in the Golgi apparatus. Cell Calcium 2007;41:405-416. [PubMed: 17140658] 
82. Duman JG, Chen L, Palmer AE, Hille B. Contributions of intracellular compartments to calcium dynamics: implicating an acidic store. Traffic 2006;7:859-872. [PubMed: 16787398]

83. Lopez JJ, Redondo PC, Salido GM, Pariente JA, Rosado JA. Two distinct $\mathrm{Ca}^{2+}$ compartments show differential sensitivity to thrombin, ADP and vasopressin in human platelets. Cell Signal 2006;18:373-381. [PubMed: 16095882]

84. Lopez JJ, Camello-Almaraz C, Pariente JA, Salido GM, Rosado JA. Ca ${ }^{2+}$ accumulation into acidic organelles mediated by $\mathrm{Ca}^{2+}$ - and vacuolar $\mathrm{H}^{+}$-ATPases in human platelets. Biochem $\mathrm{J}$ 2005;390:243-252. [PubMed: 15847604]

85. Klemper MS. An adenosine triphosphate-dependent calcium uptake pump in human neutrophil lysosomes. J Clin Invest 1985;76:303-310. [PubMed: 3926820]

86. Lemons RM, Thoene JG. Mediated calcium transport by isolated human fibroblast lysosomes. J Biol Chem 1991;266:14378-14382. [PubMed: 1830585]

87. Ezaki J, Himeno M, Kato K. Purification and characterization of $\mathrm{Ca}^{2+}-\mathrm{Mg}^{2+}-$ ATPase in rat liver lysosomal membranes. J Biochem 1992;112:33-39. [PubMed: 1331035]

88. Adachi T, Arai K, Ohkuma S. A comparative study of $\mathrm{Ca}^{2+}-\mathrm{Mg}^{2+}$-ATPase on the lysosomal membrane and ecto-ATPase on the plasma membrane from rat liver. Biol Pharm Bull 1996;19:12911297. [PubMed: 8913499]

89. Goncalves PP, Meireles SM, Neves P, Vale MG. Distinction between $\mathrm{Ca}^{2+}$ pump and $\mathrm{Ca}^{2+} / \mathrm{H}^{+}$ antiport activities in synaptic vesicles of sheep brain cortex. Neurochem Int 2000;37:387-396. [PubMed: 10825579]

90. Shigaki T, Rees I, Nakhleh L, Hirschi KD. Identification of three distinct phylogenetic groups of CAX cation/proton antiporters. J Mol Evol 2006;63:815-825. [PubMed: 17086450]

91. Cunningham KW, Fink GR. Calcineurin inhibits VCX1-dependent $\mathrm{H}^{+} / \mathrm{Ca}^{2+}$ exchange and induces $\mathrm{Ca}^{2+}$-ATPases in Saccharomyces cerevisiae. Mol Cell Biol 1996;16:2226-2237. [PubMed: 8628289]

92. Hirschi KD, Zhen RG, Cunningham KW, Rea PA, Fink GR. CAX1, an $\mathrm{H}^{+} / \mathrm{Ca}^{2+}$ antiporter from Arabidopsis. Proc Natl Acad Sci U S A 1996;93:8782-8786. [PubMed: 8710949]

93. Salceda R, Sanchez-Chavez G. Calcium uptake, release and ryanodine binding in melanosomes from retinal pigment epithelium. Cell Calcium 2000;27:223-229. [PubMed: 10858668]

94. Krieger-Brauer HI, Gratzl M. Effects of monovalent and divalent cations on $\mathrm{Ca}^{2+}$ fluxes across chromaffin secretory membrane vesicles. J Neurochem 1983;41:1269-1276. [PubMed: 6413655]

95. Ginger RS, Askew SE, Ogborne RM, Wilson S, Ferdinando D, Dadd T, Smith AM, Kazi S, Szerencsei RT, Winkfein RJ, Schnetkamp PP, Green MR. SLC24A5 encodes a trans-Golgi network protein with potassium-dependent sodium-calcium exchange activity that regulates human epidermal melanogenesis. J Biol Chem 2008;283:5486-5495. [PubMed: 18166528]

96. Zhou XL, Batiza AF, Loukin SH, Palmer CP, Kung C, Saimi Y. The transient receptor potential channel on the yeast vacuole is mechanosensitive. Proc Natl Acad Sci USA 2003;100:7105-7110. [PubMed: 12771382]

97. Puertollano R, Kiselyov K. TRPMLs: in sickness and in health. Am J Physiol Renal Physiol 2009;296:F1245-F1254. [PubMed: 19158345]

98. Ishibashi K, Suzuki M, Imai M. Molecular cloning of a novel form (two-repeat) protein related to voltage-gated sodium and calcium channels. Biochem Biophys Res Commun 2000;270:370-376. [PubMed: 10753632]

99. Ladenburger EM, Korn I, Kasielke N, Wassmer T, Plattner H. An Ins $(1,4,5) \mathrm{P}_{3}$ receptor in Paramecium is associated with the osmoregulatory system. J Cell Sci 2006;119:3705-3717. [PubMed: 16912081]

100. Allen GJ, Muir SR, Sanders D. Release of $\mathrm{Ca}^{2+}$ from individual plant vacuoles by both $\mathrm{InsP}_{3}$ and cyclic ADP-ribose. Science 1995;268:735-737. [PubMed: 7732384]

101. Walensky LD, Snyder SH. Inositol 1,4,5-trisphosphate receptors selectively localized to the acrosomes of mammalian sperm. J Cell Biol 1995;130:857-869. [PubMed: 7642703]

102. Gerasimenko OV, Gerasimenko JV, Belan PV, Petersen OH. Inositol trisphosphate and cyclic ADPribose-mediated release of $\mathrm{Ca}^{2+}$ from single isolated pancreatic zymogen granules. Cell 1996;84:473-480. [PubMed: 8608601] 
103. Lee HC, Aarhus R. A derivative of NADP mobilizes calcium stores insensitive to inositol trisphosphate and cyclic ADP-ribose. J Biol Chem 1995;270:2152-2157. [PubMed: 7836444]

104. Berridge G, Dickinson G, Parrington J, Galione A, Patel S. Solubilization of receptors for the novel $\mathrm{Ca}^{2+}$-mobilizing messenger, nicotinic acid adenine dinucleotide phosphate. J Biol Chem 2002;277:43717-43723. [PubMed: 12223470]

105. Yamasaki M, Masgrau R, Morgan AJ, Churchill GC, Patel S, Ashcroft SJH, Galione A. Organelle selection determines agonist-specific $\mathrm{Ca}^{2+}$ signals in pancreatic acinar and beta cells. J Biol Chem 2004;279:7234-7240. [PubMed: 14660554]

106. Churchill GC, O’Neil JS, Masgrau R, Patel S, Thomas JM, Genazzani AA, Galione A. Sperm deliver a new messenger: NAADP. Curr Biol 2003;13:125-128. [PubMed: 12546785]

107. Pandey V, Chuang CC, Lewis AM, Aley P, Brailoiu E, Dun N, Churchill GC, Patel S. Recruitment of NAADP-sensitive acidic $\mathrm{Ca}^{2+}$ stores by glutamate. Biochem J. 2009 (in press).

108. Cancela JM, Churchill GC, Galione A. Coordination of agonist-induced $\mathrm{Ca}^{2+}$-signalling patterns by NAADP in pancreatic acinar cells. Nature 1999;398:74-76. [PubMed: 10078532]

109. Patel S, Churchill GC, Galione A. Coordination of $\mathrm{Ca}^{2+}$ signalling by NAADP. Trends Biochem Sci 2001;26:482-489. [PubMed: 11504624]

110. Lim D, Kyozuka K, Gragnaniello G, Carafoli E, Santella L. NAADP ${ }^{+}$initiates the $\mathrm{Ca}^{2+}$ response during fertilization of starfish oocytes. FASEB J 2001;15:2257-2267. [PubMed: 11641253]

111. Brailoiu E, Churamani D, Pandey V, Brailoiu GC, Tuluc F, Patel S, Dun NJ. Messenger-specific role for NAADP in neuronal differentiation. J Biol Chem 2006;281:15923-15928. [PubMed: 16595650]

112. Navazio L, Bewell MA, Siddiqua A, Dickinson GD, Galione A, Sanders D. Calcium release from the endoplasmic reticulum of higher plants elicited by the NADP metabolite nicotinic acid adenine dinucleotide phosphate. Proc Natl Acad Sci U S A 2000;97:8693-8698. [PubMed: 10890899]

113. Gross JD. Acidic $\mathrm{Ca}^{2+}$ stores, excitability, and cell patterning in Dictyostelium discoideum. Eukaryot Cell 2009;8:696-702. [PubMed: 19252125]

114. Miranda K, Docampo R, Grillo O, de Souza W. Acidocalcisomes of trypanosomatids have speciesspecific elemental composition. Protist 2004;155:395-405. [PubMed: 15648720] 


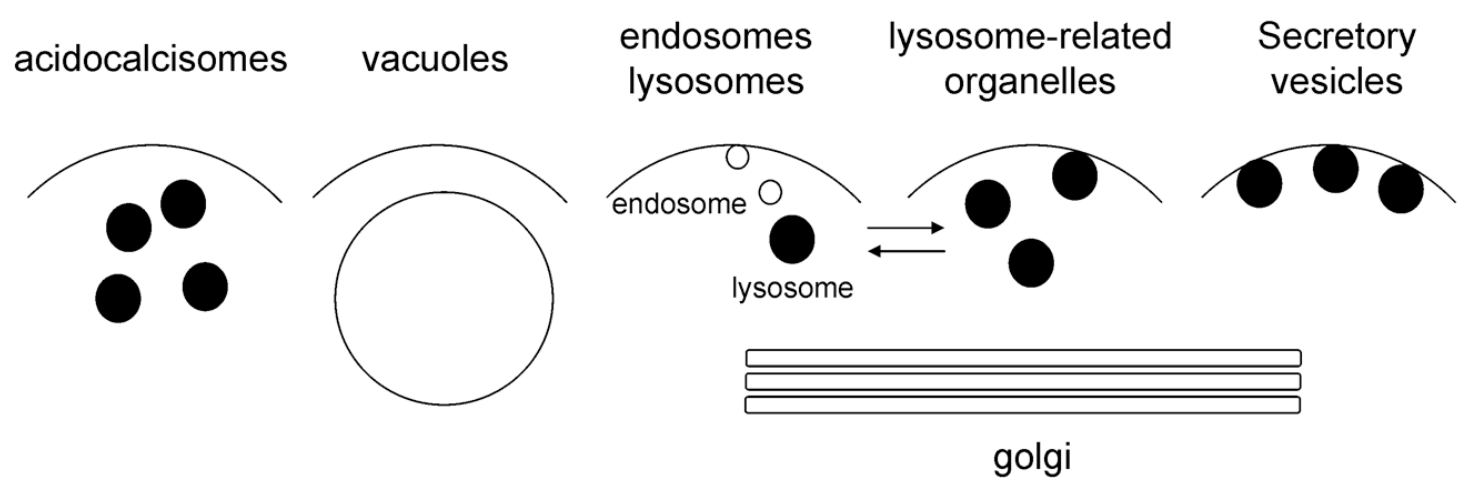

Figure 1. The acidic calcium stores

Schematic representation of acidic organelles that contain high concentrations of calcium. 

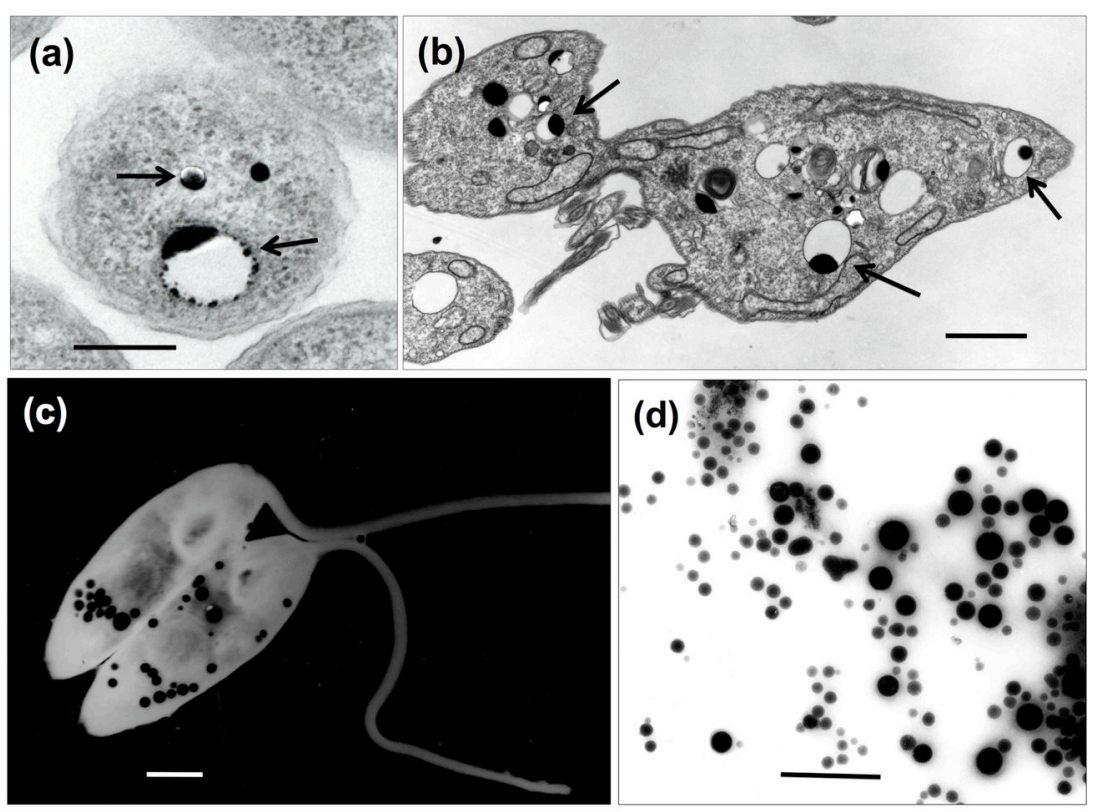

Figure 2. Acidocalcisomes in whole cells and subcellular fractions

(a), (b), ultrathin sections of Agrobacterium tumefaciens (a) or Trypanosoma brucei procyclic forms (b) showing the acidocalcisomes as empty vesicles with electron-dense inclusions (arrows). (c), (d), visualization of acidocalcisomes in whole unfixed Herpetomonas anglusteri and Trypanosoma cruzi acidocalcisome fraction obtained by iodixanol centrifugation [6] allowed to adhere to Formvar- and carbon-coated grids and then observed by direct transmission electron microscopy (using an energy filter in (c)).Acidocalcisomes (black granules) appear disperse in the cytoplasm (c) or fraction (d). Scale bars: (a), $0.2 \mu \mathrm{m}$; (b), $2 \mu \mathrm{m}$; (c), $0.5 \mu \mathrm{m}$; (d), $1 \mu \mathrm{m}$. (a) was taken by Manfredo Seufferheld. (c) is reproduced with permission from ref. [114]. 

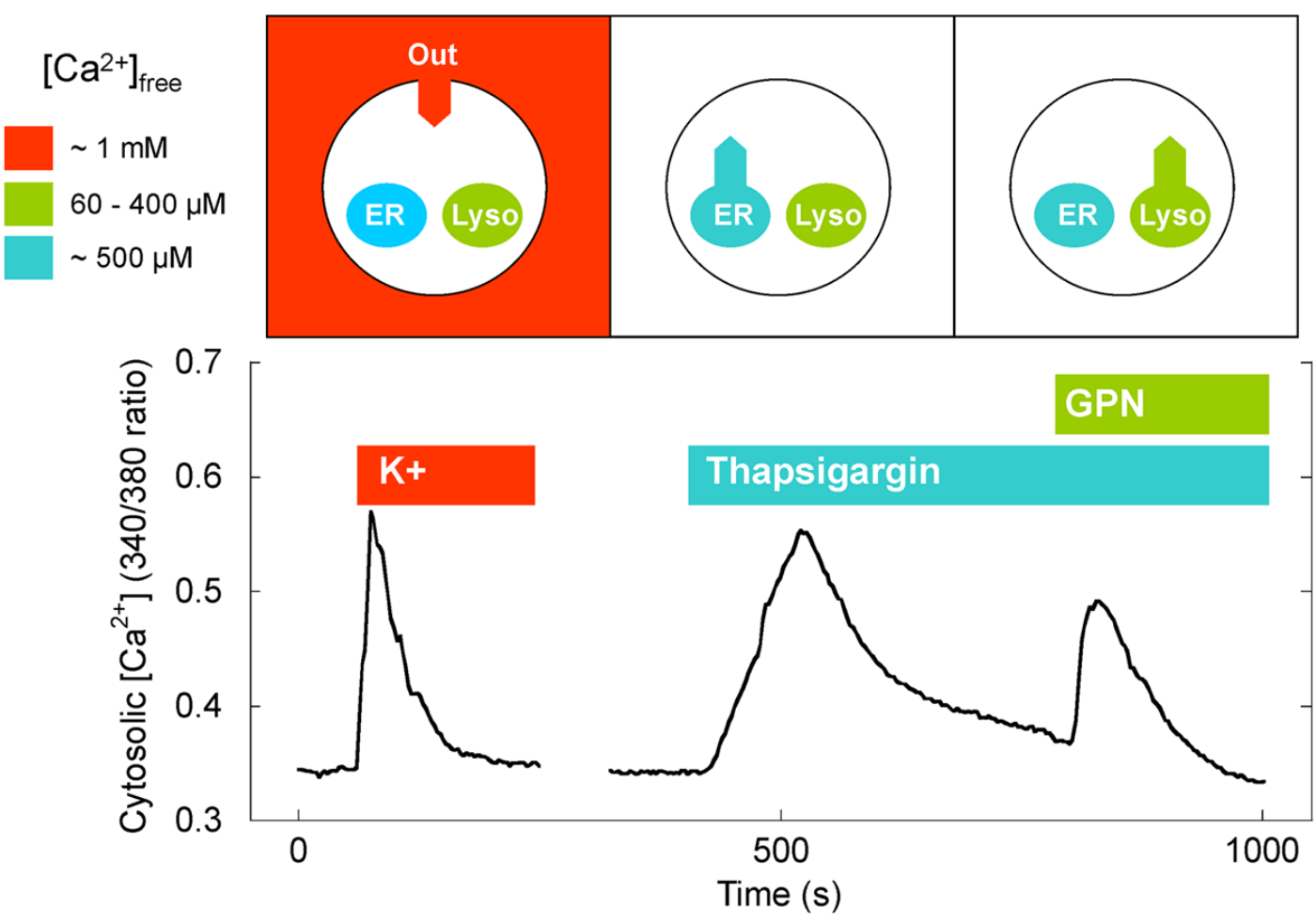

Figure 3. Lysosomal calcium stores in neurons

Top, Schematic representation of a cell depicting high levels of calcium on the outside of the cell (red), within endoplasmic reticulum calcium stores (blue) and within lysosomal calcium stores (green). The concentration of free calcium in these compartments $\left(\left[\mathrm{Ca}^{2+}\right]_{\text {free }}\right)$ is listed. The bottom panel shows measurements of cytosolic calcium levels in hippocampal neurons upon depolarization with high $\mathrm{K}^{+}$(to stimulate calcium influx from the extracellular space). The cells were then sequentially stimulated (in the absence of external calcium) with thapsigargin (to stimulate depletion of ER calcium stores) and GPN (to lyse lysosomal calcium stores). All three maneuvers raise the cytosolic calcium concentration. The data in the bottom panel was obtained by George Dickinson. 
Calcium ATPases

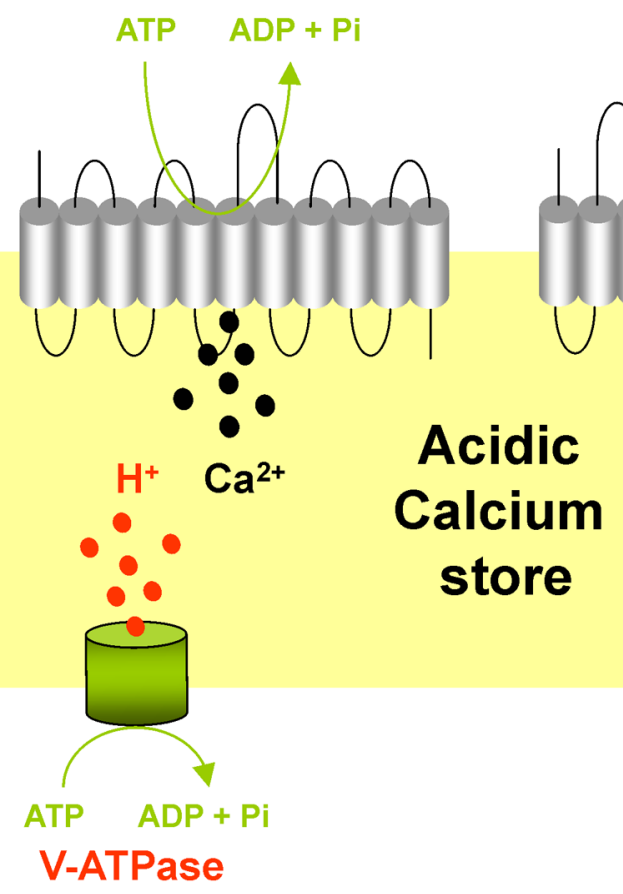

Calcium exchangers

$\mathrm{H}^{+} / \mathrm{Na}^{+}$
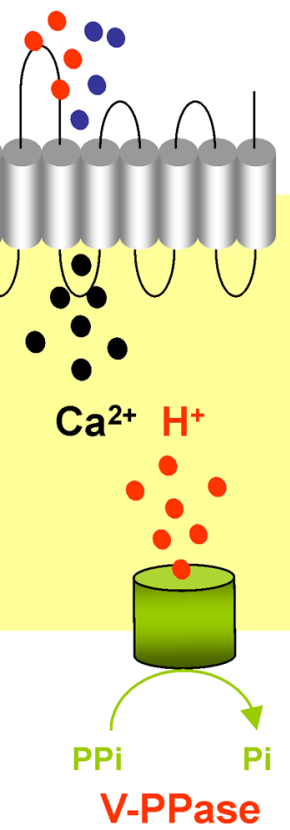

Box 1 Figure I. Calcium transport in to acidic calcium stores Schematic of an acidic calcium store depicting calcium pumps and exchangers that mediate calcium uptake (top) and V-ATPases and V-PPases responsible for acidification (bottom). 


\section{TRP channels Two-pore channels "ER" channels}

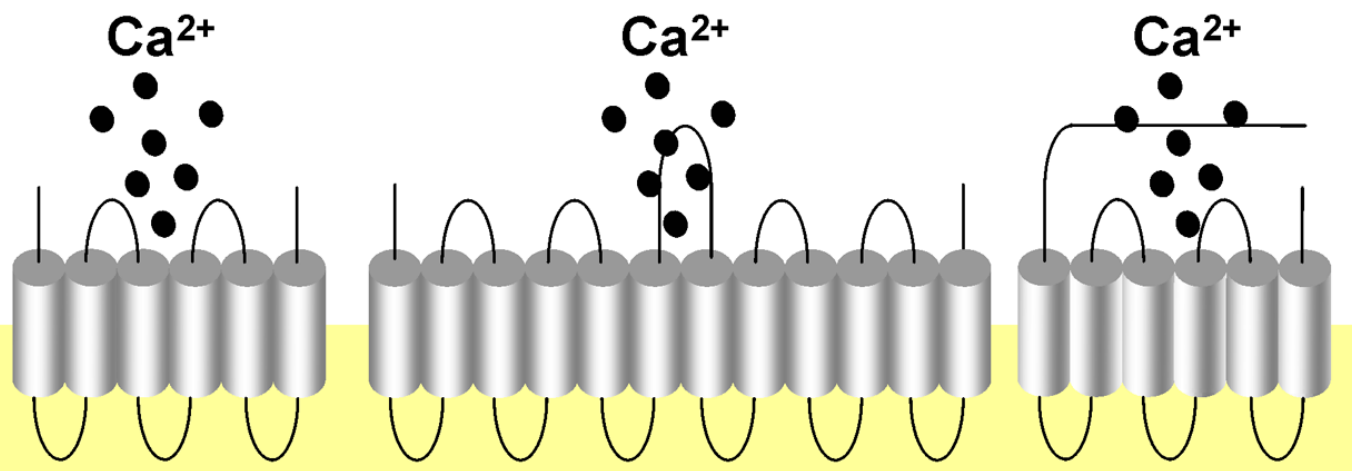

\section{Acidic Calcium store}

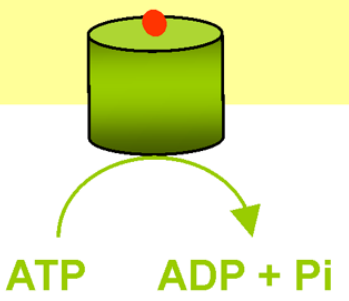

V-ATPase

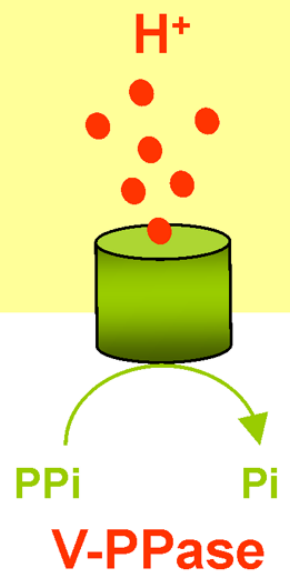

Box 2 Figure II. Calcium release from acidic calcium stores

Schematic of an acidic calcium store depicting calcium-permeable channels (top) which mediate calcium release (top) and V-ATPases and V-PPases responsible for acidification (bottom). 
NAADP

\section{Global}

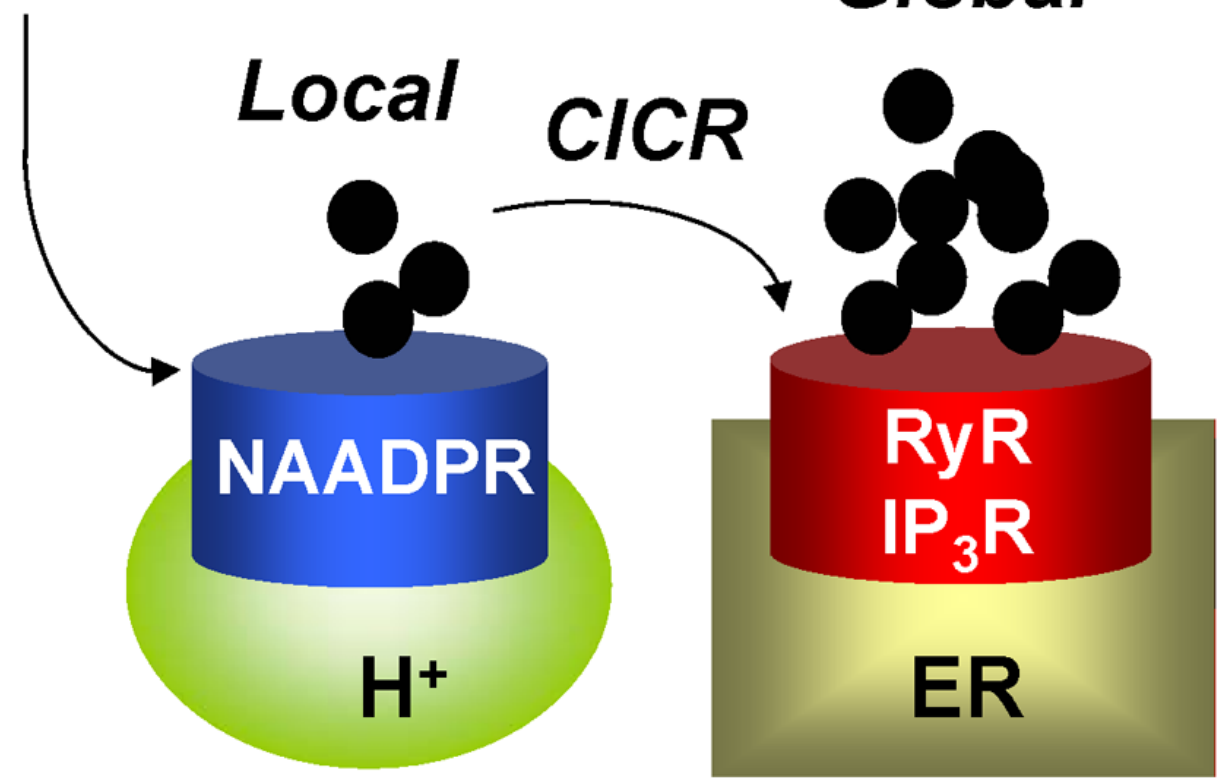

Box 3 Figure III. NAADP-mediated channel "chatter"

Schematic showing proposed mechanism of action of NAADP starting with the generation of a local calcium signal from an acidic calcium store and subsequent amplification by the ER resulting in a global calcium signal. 
Table 1

$\mathrm{Ca}^{2+}$ transport into acidic stores

\begin{tabular}{|c|c|c|c|}
\hline Calcium pump/exchanger & General characteristics & $\begin{array}{l}\text { Associated Human Genetic } \\
\text { Diseases }\end{array}$ & Acidic store \\
\hline $\begin{array}{l}\text { PMCA-type } \mathrm{Ca}^{2+} \text {-ATPase } \\
\text { (subgroup IIB) }\end{array}$ & $\begin{array}{l}\text { P-type, } 10 \text { TMD } \\
\mathrm{Ca}^{2+} \text { transport in exchange for } \\
\mathrm{H}^{+} \\
\text {One } \mathrm{Ca}^{2+} \text { binding site }\end{array}$ & Hereditary deafness (PMCA2) & $\begin{array}{l}\text { Acidocalcisomes [6] } \\
\text { Yeast vacuole [12] } \\
\text { Dictyostelium contractile vacuole } \\
{[11]} \\
\text { Plant vacuole }[80]\end{array}$ \\
\hline $\begin{array}{l}\text { SERCA-type } \mathrm{Ca}^{2+} \text {-ATPase } \\
\text { (subgroup IIA) }\end{array}$ & $\begin{array}{l}\text { P-type, } 10 \text { TMD } \\
\mathrm{Ca}^{2+} \text { transport in exchange for } \\
\mathrm{H}^{+} \\
\text {Two Ca }{ }^{2+} \text { binding sites Specific } \\
\text { inhibition by thapsigargin and } \\
\text { cyclopiazonic acid }\end{array}$ & $\begin{array}{l}\text { Brody s disease (SERCA1) } \\
\text { Darier-White s disease } \\
\text { (SERCA2) }\end{array}$ & $\begin{array}{l}\text { Lysosome-related organelles }[83,84] \\
\text { Secretory granules }[35,37,82] \\
\text { Golgi apparatus }[81]\end{array}$ \\
\hline $\begin{array}{l}\text { SPCA-type } \mathrm{Ca}^{2+} \text {-ATPase } \\
\text { (subgroup IIA) }\end{array}$ & $\begin{array}{l}\text { P-type, } 10 \mathrm{TMD} \\
\mathrm{Ca}^{2+} \text { and } \mathrm{Mn}^{2+} \text { transport } \\
\text { One } \mathrm{Ca}^{2+} / \mathrm{Mn}^{2+} \text { binding site }\end{array}$ & $\begin{array}{l}\text { Hailey-Hailey s disease } \\
\text { (SPCA1) }\end{array}$ & $\begin{array}{l}\text { Secretory granules [36] } \\
\text { Golgi apparatus [81] }\end{array}$ \\
\hline Unidentified $\mathrm{Ca}^{2+}$-ATPase & $\begin{array}{l}\text { P-type, ND } \\
\mathrm{Ca}^{2+} \text { transport }\end{array}$ & ND & $\begin{array}{l}\text { Lysosomes [86-88] } \\
\text { Synaptic vesicles [89] }\end{array}$ \\
\hline $\mathrm{Ca}^{2+} / \mathrm{H}^{+}$exchanger $(\mathrm{CAX})$ & $\begin{array}{l}11 \text { TMD (two "half-proteins" } \\
\text { separated by an "acidic motif") } \\
\text { Reversible }\end{array}$ & ND & $\begin{array}{l}\text { Acidocalcisomes [6] } \\
\text { Yeast vacuole [91] } \\
\text { Plant vacuole [92] } \\
\text { Melanosomes } \#[93] \\
\text { Secretory granules } \# \text { [37] } \\
\text { Synaptic vesicles } \# \text { [89] }\end{array}$ \\
\hline $\mathrm{Na}^{+} / \mathrm{Ca}^{2+}$ exchanger (NCX) & $\begin{array}{l}11 \mathrm{TMD}, \mathrm{Ca}^{2+} \text { exchange for } \mathrm{Na}^{+} \\
\text {Reversible }\end{array}$ & ND & $\begin{array}{l}\text { Secretory granules }{ }^{\#}[37,94] \\
\text { Melanosomes (NCKX5) [71] }\end{array}$ \\
\hline
\end{tabular}

\# The molecular identity of the exchanger is unknown. ND, not determined; P-type: characterized by the formation of a phosphorylated enzyme intermediate, and inhibited by vanadate; TMD, transmembrane domains; NCKX5, potassium-dependent $\mathrm{Na}^{2+} / \mathrm{Ca}^{2+}$ exchanger 
Table 2

$\mathrm{Ca}^{2+}$ transport out of acidic stores

\begin{tabular}{|l|l|l|l|}
\hline Calcium permeable channel & General characteristics & $\begin{array}{l}\text { Associated human genetic } \\
\text { diseases }\end{array}$ & Acidic store \\
\hline $\begin{array}{l}\text { TRP channels (TRPML1, TRPML2, } \\
\text { TRPML3, TRPM2, TRPV2) }\end{array}$ & $6 \mathrm{TMD}$ & Mucolipidosis IV (TRPML1) & $\begin{array}{l}\text { Yeast vacuole [15] } \\
\text { Endosomes [46,97] } \\
\text { Lysosomes [42,97] }\end{array}$ \\
\hline Two-pore channels & $12 \mathrm{TMD}$ & ND & $\begin{array}{l}\text { Plant vacuole [17] } \\
\text { Endosomes [47,48] } \\
\text { Lysosomes [47-49] }\end{array}$ \\
\hline Inositol trisphosphate/Ryanodine receptors & $6 \mathrm{TMD}$ & $\begin{array}{l}\text { Congenital myopathies, } \\
\text { Malignant hyperthermia } \\
\text { (RYR1) Arrhytmias (RYR2) }\end{array}$ & $\begin{array}{l}\text { Paramecium contractile vacuole } \\
\text { [99] } \\
\text { Plant vacuole [100] } \\
\text { Lysosome-related organelles [93, } \\
101] \\
\text { Golgi complex [39] } \\
\text { Secretory granules [34] }\end{array}$ \\
\hline
\end{tabular}

ND, not determined; TMD, transmembrane domains; TRPML, TRP mucolipins; TRPM, TRP melastatins; TRPV, TRP vallinoid 